\title{
INFLUENCE OF OPERATIONAL CONDITIONS OF MECHANIZED HARVESTING ON SUGARCANE LOSSES AND IMPURITIES
}

\author{
Murilo B. Martins ${ }^{*}$, Daniel Ruiz ${ }^{2}$
}

${ }^{1 *}$ Corresponding author. Universidade Estadual de Mato Grosso do Sul (UEMS)/ Cassilândia - MS, Brasil.
E-mail: mbm_martins@hotmail.com | ORCID ID: https://orcid.org/0000-0002-8759-0917

\begin{abstract}
KEYWORDS
agricultural mechanization, harvest, quality, Saccharum spp.
\end{abstract}

\begin{abstract}
Operational conditions of mechanized harvesting can affect the quality of harvested sugarcane. Therefore, the aim of this study was to assess the influence of the displacement speed and cutting height on the quality of the raw material during the mechanized harvest of sugarcane. Vegetable losses were accounted for in the field by manual collection of the fractions left after harvest. Vegetable and mineral impurities were determined at the processing stage in the laboratory. Both the displacement speed and cutting height did not affect vegetable losses. However, the increase in vegetal impurities occurred at higher displacement speeds, whereas lower cutting heights resulted in higher amounts of mineral impurities.
\end{abstract}

\section{INTRODUCTION}

Mechanized harvesting of sugarcane has been growing in production systems in Brazil, from $24.4 \%$ in the $2007 / 08$ season to $91.6 \%$ in the $2018 / 19$ season (CONAB, 2018). This is considered one of the most important processes in the agricultural production of sugarcane, as it controls the operational costs and influences the quality of the raw material (Santos et al., 2014).

During the harvesting process, several factors can cause crop quality reduction. These include operating conditions (operator, displacement speed, and cutting height), the crop (sugarcane size and variety), and the environment (work shift and declivity), which can lead to poor quality work (Voltarelli et al., 2018).

According to Neves (2015), the losses represent all the sugarcane parts that can be industrialized and remain in the field after harvest. The increase in the losses of raw material is related to the harvesting speed; an increase in the harvesting speed leads to an increase in vegetable losses (Ramos et al., 2016).

Another relevant aspect to be evaluated in the mechanized harvesting of sugarcane is the vegetal and mineral impurities. This is because when the impurities are taken to the processing unit with the harvested material, they interfere with the process of sugarcane juice extraction in the mills, clarification of the broth, and the formation of sugar crystals, reducing the color quality of the sugar produced (Cassia et al., 2015). In order to minimize the presence of impurities and losses during the harvesting process, adoption of technologies for the harvesters is essential, in addition to improving efficiency of the machines (Ma et al., 2015).

Therefore, since the harvest operational conditions can affect the quality of the raw material to be processed, the objective of this study was to assess the influence of displacement speed and cutting height on the quality of the raw material during the mechanized harvesting of sugarcane.

\section{MATERIAL AND METHODS}

The experiment was carried out in a sugarcane production unit in Bariri, São Paulo State, Brazil, within the geographical coordinates $22^{\circ} 5^{\prime} \mathrm{S}$ and $48^{\circ} 50^{\prime} \mathrm{W}$. The local climate is classified as Aw according to Köppen's classification.

For mechanized harvesting without prior burning, a John Deere ${ }^{\mathrm{TM}}$ model $\mathrm{CH} 670$ harvester was used, with a rated engine of $279.49 \mathrm{~kW}(380 \mathrm{hp})$, driven by track, and with integrated control of the base cut (CICB). The base cutoff pressure, the primary extractor, and engine rotation were setvat $1,000 \mathrm{psi}, 14.3 \mathrm{~Hz}(860 \mathrm{rpm})$, and $36.6 \mathrm{~Hz}$ $(2,200 \mathrm{rpm})$, respectively. The experimental area had the variety RB855156 planted on beds at a dense crop spacing of $1.50 \mathrm{~m} \times 0.90 \mathrm{~m}$, with average yield of $122 \mathrm{Mg} \mathrm{ha}^{-1}$.

Three cutting heights, i.e., $3.0 \mathrm{~cm}(\mathrm{H} 1), 5.0 \mathrm{~cm}(\mathrm{H} 2)$, and $7.0 \mathrm{~cm}(\mathrm{H} 3)$, were selected based the soil surface. Two speed conditions, i.e., $2.0 \mathrm{~km} \mathrm{~h}^{-1}$ (S1) and $4.0 \mathrm{~km} \mathrm{~h}^{-1}$ (S2),

\footnotetext{
${ }^{2}$ Raízen Energia S/A - Unidade Diamante/ Jaú - SP, Brasil.
} 
were used. The treatments were prepared in six replications, with a total of 36 plots arranged in a completely randomized design. Each plot was $100 \mathrm{~m}$ long in the direction of harvesting.

Vegetable losses were determined after passing through the sugarcane harvester in a demarcated area with dimensions of $2.4 \mathrm{~m} \times 4.2 \mathrm{~m}$, totaling a sample area of 10 $\mathrm{m}^{2}$. Manual collection of the fractions left in the field was performed according to the methodology of the production unit. The losses were calculated in absolute form $\left(\mathrm{Mg} \mathrm{ha}^{-1}\right)$, multiplying the final value by weight per 1,000 samples. The value obtained was divided by the productivity plus the value of losses to determine the percentage value, according to [eq. (1)].

$$
\mathrm{Pc}=(\mathrm{PF} / \mathrm{P}+\mathrm{PF}) \times 100
$$

Where:

$$
\begin{aligned}
& \mathrm{Pc} \text { is percentage of losses in the field }(\%) \text {; } \\
& \mathrm{PF} \text { is field losses }\left(\mathrm{Mg} \cdot \mathrm{ha}^{-1}\right) \text {; } \\
& \mathrm{P} \text { is sugarcane productivity }\left(\mathrm{Mg} \cdot \mathrm{ha}^{-1}\right) \text {, } \\
& 100 \text { is the conversion factor. }
\end{aligned}
$$

Vegetal and mineral impurities were collected from the loads obtained in each treatment through an oblique probe at the production unit, and were quantified in the laboratory, according to the production unit methodology. A sample of $10 \mathrm{~kg}$ of harvested sugarcane was separated into green leaves, straw, and cane tips to determine the vegetal impurities. To determine the mineral impurities, such as soil and stones, the samples were separated from the total sample by a sieve.

The mineral impurities were quantified by the calcination method, which considers the difference between the ash content in samples with mineral impurities and clean samples without the presence of mineral impurities in the pellets, quantified in kilograms of mineral impurities per ton of the harvested sugarcane.

Statistical analysis was performed using Minitab software, version 16. When analysis of variance (ANOVA) showed a significant effect, Tukey' s test was applied at 5\% probability $(\mathrm{p}<0.05)$.

\section{RESULTS AND DISCUSSION}

Average vegetal losses are presented in Table 1. There was no interaction between cutting height and displacement speed.

TABLE 1. Average vegetal losses (\%).

Cutting height $(\mathrm{cm})$

$\mathrm{H} 1$
$\mathrm{H} 2$
$\mathrm{H} 3$

Average (\%)

7.4 a

Displacement speed $\left(\mathrm{km} \mathrm{h}^{-1}\right)$

Average (\%)

\begin{tabular}{cccc}
\hline & ANOVA & \\
\hline F test (height) & F test (speed) & F test (interaction) & CV $(\%)$ \\
\hline $0.17^{\mathrm{NS}}$ & $0.00^{\mathrm{NS}}$ & $0.57^{\mathrm{NS}}$ & 36.60 \\
\hline
\end{tabular}

Averages followed by the same uppercase letters in a column and lowercase letters in a row do not differ by Tukey's test ( $\alpha=5 \%)$. CV Coefficient of variation; * significant at $5 \%$ probability; ${ }^{\text {NS }}$ not significant.

Both the displacement speed of the harvester and the cutting height did not show statistical differences in the vegetal losses (Table 1).

Other authors, such as Voltarelli et al. (2015), obtained lower values of vegetal losses by monitoring the losses in the mechanized harvesting of sugarcane by using control charts, with mean total losses of $2.5 \%$. The highest amount of losses found in the present study may be due to the dense crop spacing, which results in a higher amount of plants when compared to other spacing levels (e.g., $1.5 \mathrm{~m}$ ) adopted for sugarcane, as well as to the high productivity of the experimental area.

For the two working speeds analyzed $\left(2.0 \mathrm{~km} \mathrm{~h}^{-1}\right.$ and $4.0 \mathrm{~km} \mathrm{~h}^{-1}$ ), vegetal losses showed similar values, indicating that this variable had no influence on these parameters. This corroborates with Neves et al. (2006) who showed that high rates of raw material losses is not associated with the harvest speed of work.

However, Ramos et al. (2016) obtained mean values of $2.0 \%$ of vegetal losses with a velocity of $4.0 \mathrm{~km} \mathrm{~h}^{-1}$, suggesting that the increase of speed during the harvesting process leads to an increase in vegetal losses. Silva et al. (2015), while evaluating visible losses during the mechanized harvesting of sugarcane, at $3.6 \mathrm{~km} \mathrm{~h}^{-1}$ speed, also found that increasing the speed resulted in increased plant losses.

The average of vegetable impurities did not show statistical differences as a function of the cutting height during the harvest but showed statistical differences for the displacement speed (Table 2). 
TABLE 2. Average vegetable impurities (\%).

Cutting height $(\mathrm{cm})$

Displacement speed $\left(\mathrm{km} \mathrm{h}^{-1}\right)$

Average (\%)

\begin{tabular}{|c|c|c|c|}
\hline & S1 & S2 & \\
\hline H1 & 6.7 & 7.9 & $7.3 \mathrm{~A}$ \\
\hline $\mathrm{H} 2$ & 8.1 & 9.1 & $8.6 \mathrm{~A}$ \\
\hline H3 & 7.7 & 10.9 & $9.3 \mathrm{~A}$ \\
\hline Average (\%) & $7.5 \mathrm{a}$ & $9.3 \mathrm{~b}$ & \\
\hline \multicolumn{4}{|c|}{ ANOVA } \\
\hline F test (height) & F test (speed) & $\mathrm{F}$ test (interaction) & CV (\%) \\
\hline $2.42^{\mathrm{NS}}$ & $5.59 *$ & $0.84^{\mathrm{NS}}$ & 23.00 \\
\hline
\end{tabular}

Averages followed by the same uppercase letters in a column and lowercase letters in a row do not differ by Tukey's test ( $\alpha=5 \%)$. CV -

Coefficient of variation; * significant at $5 \%$ probability; ${ }^{\text {NS }}$ not significant.

According to Marques et al. (2014), after harvest, technical analyses during the processing of the sugarcane samples demonstrated that the presence of straw and impurities impairs its quality.

A higher harvest speed $\left(4.0 \mathrm{~km} \mathrm{~h}^{-1}\right)$ generated a higher amount of vegetable impurities $(9.3 \%)$, because there was no change in the primary extractor rotation of the harvester as a function of harvest speed. The large amount of sugarcane harvested at the highest speed may have led to a lag in the cleaning system.

In addition to the harvest displacement speed, other components should be regulated. As described by Martins et al. (2017), the primary extractor rotation influences the amount of vegetable impurities.
According to Ramos et al. (2016), the amount of vegetable impurities increases with the harvesting speed. The author also reports that the aspects of the crop in the field can also contribute to the indices of vegetal impurities. For example, the erect and linear position of sugarcane in the field allows the use of tip cutters and prevents other materials from being carried next to the load in transhipment vehicles, thereby reducing the content of vegetable impurities.

As reported by Gimenez et al. (2016), areas harvested without previous burning of sugarcane leads to $15 \%$ more vegetal and mineral impurities during industrial processing.

Table 3 shows the mean values of the mineral impurities. For the displacement speeds, there was no difference in mineral impurities. However, mineral impurities increased with the cutting height.

TABLE 3. Average mineral impurities $\left(\mathrm{kg} \mathrm{TC}^{-1}\right)$.

Cutting height $(\mathrm{cm})$

Displacement speed $\left(\mathrm{km} \mathrm{h}^{-1}\right)$

Average (\%)

\begin{tabular}{lccc}
\cline { 2 - 3 } & $\mathrm{S} 1$ & $\mathrm{~S} 2$ & \\
\hline $\mathrm{H} 1$ & 10.3 & 9.1 & $9.7 \mathrm{~A}$ \\
$\mathrm{H} 2$ & 8.1 & 10.0 & $9.1 \mathrm{AB}$ \\
$\mathrm{H} 3$ & 6.9 & 6.2 & $6.6 \mathrm{~B}$ \\
Average (\%) & $8.4 \mathrm{a}$ & $8.5 \mathrm{a}$ & \\
\hline \multicolumn{2}{c}{ F test (height) } & ANOVA & $\mathrm{CV}(\%)$ \\
\hline 5.00* & F test (speed) & F test (interaction) & 25.64 \\
\hline
\end{tabular}

Averages followed by the same uppercase letters in a column and lowercase letters in a row do not differ by Tukey's test ( $\alpha=5 \%$ ). CV Coefficient of variation; * significant at $5 \%$ probability; ${ }^{\mathrm{NS}}$ not significant.

The highest value of mineral impurities $(9.7 \mathrm{~kg}$ $\mathrm{TC}^{-1}$ ) occurred at the lowest cutting height $(3 \mathrm{~cm})$. Due to the lower height, the cut-off knives are closer to the ground, and irregularity of the ground surface can lead to the collection of mineral materials such as soil. However, the increase in the cutting height tends to reduce these impurities, as observed in this study.

During the harvesting process, factors such as topography and slope of the area, among others, can lead to low quality of work (Voltarelli et al., 2018). Thus, leveling of the area is required to reduce mineral impurities.
Currently, technologies are invested in the machines to assist in the harvesting process, such as the use of a mechanism to control cutting height and reduce impurities in the harvested sugarcane. The absence of a floating cutting mechanism can increase the amount of mineral impurities in the harvested sugarcane, reducing the quality of the raw material supplied (Gray et al., 2009).

Alcantara et al. (2017) studied the harvesting methods for different work shifts and their influence on mineral impurities, and obtained higher values compared to the present study. The authors justified their results based 
on the lack of a floating mechanism on the base cut of the harvester and light conditions. As observed by Giachini et al. (2016) during night harvesting, owing to the absence of natural light, the content of mineral impurities was higher because of impaired visibility of operators.

\section{CONCLUSIONS}

The operational conditions of mechanized harvesting interfere with the quality of raw materials. The increase in harvesting speed leads to higher amounts of vegetable impurities, whereas a lower cutting height increases the amount of mineral impurities.

\section{REFERENCES}

Alcantara AS, Ormond ATS, Júnior PRS, Silva RP, Kazama EH (2017) Shifts and harvesing systems on quality of impurities samples in sugarcane. Engenharia Agrícola 37(3):510-519. DOI: http://dx.doi.org/10.1590/1809-4430Eng.Agric.v37n3p510-519/2017

Cassia MT, Franzé RV, Pizzinatto AAS (2015) Controle de qualidade de operações - Resultados de operações em unidades sucroenergéticas. In: Belardo GC, Cassia MT, Silva RP (ed). Processos agrícolas e mecanização da canade-açúcar. SBEA, p. 393-413.

CONAB - Companhia Nacional de Abastecimento (2018) Acompanhamento da safra brasileira: cana-de-açúcar, terceiro levantamento. CONAB. Available:

https://www.conab.gov.br/info-agro/safras/cana. Accessed: Apr 08, 2019.

Giachini CF, Ramos CRG, Lyra GA, Gamero CA, Lanças KP (2016) Consumo de combustível e perdas de cana-deaçúcar durante a colheita diurna e noturna. Energia na Agricultura 31(1):10-16. DOI:

https://doi.org/10.17224/EnergAgric.2016v31n1p10-16

Gimenez AZ, Franzé RV, Madaleno LL (2016) Teores de impurezas vegetais e a concentração do amido no caldo de cana. Ciência \& Tecnologia 8(1):42-54.

Gray GR, Magalhães PSG, Braunbeck AO (2009) Suspensão pantográfica para corte de base de cana-deaçúcar. Ciência Rural 39(3):766-771. DOI: https://doi.org/10.1590/S0103-84782008005000096

Ma S, Scharf PA, Karkee M, Zhang Q (2015) Performance evaluation of a chopper harvester in hawaiian sugarcane fields. Transactions of the American Society of Agricultural and Biological Engineers 58:271-279.
Marques TA, Junior ELD, Rampazo ÉM, Marques PAA (2014) Palhiço, polímero hidrogel e sistemas de plantio nos parâmetros de biometria, tecnologia, energia e produtividade de cana-de-açúcar. Bioscience Journal 30(5):501-511.

Martins MB, Testa JVP, Drudi FS, Sandi J, Lanças KP (2017) Losses in the mechanized harvest of sugarcane as a function of working speed and rotation of the primary extractor. Científica 45(3):218-222. DOI: http://dx.doi.org/10.15361/1984-5529.2017v45n3p218-222

Neves JLM (2015) Avaliação da colheita mecanizada Avaliações de perdas quantitativas na colheita de cana-deaçúcar. In: Belardo GC, Cassia MT, Silva RP (ed) Processos agrícolas e mecanização da cana-de-açúcar, SBEA, p. 367-373.

Neves JLM, Magalhães PSG, Moraes EE, Araújo FVM (2006) Avaliação de perdas invisíveis na colheita mecanizada em dois fluxos de massa de cana-de-açúcar. Engenharia Agrícola 26(3):787-94. DOI: http://dx.doi.org/10.1590/S0100-69162006000300016

Ramos CRG, Lanças KP, Santos RS, Silva RL (2016) Perdas e impurezas na colheita mecanizada de cana-deaçúcar utilizando diferentes configurações de trabalho da colhedora. Energia na Agricultura 31(4):317-327. DOI: http://dx.doi.org/10.17224/EnergAgric.2016v31n4p317-327

Santos NBD, Silva RP, Junior CGD (2014) Economic analysis for sizing of sugarcane (Saccharum spp.) mechanized harvesting. Engenharia Agrícola 34(5):945954. DOI: http://dx.doi.org/10.1590/S010069162014000500013

Silva RC, Oliveira TC, Figueiredo ZN, Caldeira DSA (2015) Perdas visíveis na colheita mecanizada de cana-deaçúcar. Engenharia na Agricultura 23(1):71-77. DOI: http://dx.doi.org/10.13083/14143984/REVENG.V23N1P71-77

Voltarelli MA, Paixão CSS, Zerbato C, Silva RP, Gazzola J (2018) Failure mode and effect analysis (FMEA) in mechanized harvest of sugarcane billets. Engenharia Agrícola 38(1):88-96. DOI: http://dx.doi.org/10.1590/18094430-Eng.Agric.v38n1p88-96/2018

Voltarelli MA, Silva RP, Zerbato C, Paixão CSS, Tavares TO (2015) Monitoring of mechanical sugarcane harvesting through control charts. Engenharia Agrícola 35(6):10791092. DOI: http://dx.doi.org/10.1590/1809-4430Eng.Agric.v35n6p1079-1092/2015 